\title{
Pengaruh Erupsi Gunung Agung Terhadap Produksi Kerajinan Patung Di Desa Sebatu, Kecamatan Tegallalang, Kabupaten Gianyar
}

Ni Wayan Ririn Putri Darmayanti a, 1, Luh Putu Kerti Pujani a, 2

1 gexrpd@gmail.com, 2 kerti_pujani@unud.ac.id

a Program Studi Sarjana Destinasi Pariwisata, Fakultas Pariwisata,Universitas Udayana, Jl. Dr. R. Goris, Denpasar, Bali 80232 Indonesia

\begin{abstract}
This research was conducted to determine the effect of Mount Agung eruption on the production of sculpture in Sebatu Village, Tegallalang District, Gianyar Regency. The types of data and sources of data used are qualitative, primary and secondary data. Data collection is conducted by observation, in-depth interviews and documentation. Analysis of the data used was qualitative data analysis to seek the relationship between the influence of the Mount Agung eruption on the qaunitity of sculpture production and the distribution network of sculpture crafts in Sebatu Village. The results of this study indicate that sculpture crafts produced in Sebatu Village are a type of contemporary sculpture that is dominated by animal statues. The production capacity of sculpture crafts in Sebatu village after the eruption of Mount Agung has increased, contrary to when the eruption occurred tourists could not come directly to order sculpture and their production capacity had declined. The working system of sculpture craftsmen has started to run normally with increasing production capacity. The distribution network of sculpture crafts in Sebatu Village can be distributed in five ways through distribution to the Sukawati art market, Balinese souvenirs, shipping by sea, shipping via cargo and distribution to the villa. From the conclusion, the Gianyar Regency Government should provide capital support for the sculpture industry, especially in Sebatu Village, Tegallalang District.There is a need to increase capital for handicraft business owners by providing financial or credit assistance for sculpture.Thus, there will be many entrepreneurs who are growing and increasing their production.
\end{abstract}

Keywords: Statue Craft, Mount Agung Eruption, and Distribution Network.

\section{PENDAHULUAN}

Industri pariwisata tidak sedikit memberi peran penting bagi perekonomian Indonesia karena dapat memberikan tambahan devisa bagi negara, selain itu dapat menambah lapangan pekerjaan bagi masyarakat sekitar objek wisata misalnya dengan adanya pedagang-pedagang kecil seperti pedagang makanan ringan dan penjual souvenir yang dapat mengurangi pengangguran dan kemiskinan (Yoeti, 2008).

Selain kegiatan pariwisata yang telah menjadi sektor unggulan di Bali, industri kerajinan juga menjadi penyumbang pendapatan daerah dan penyerap tenaga kerja yang cukup besar. Dengan berkembangnya industri pariwisata di Bali, kebutuhan akan kerajinan juga semakin meningkat. Di samping itu, melalui industri kerajinan, masyarakat lokal dapat sekaligus melestarikan hasil kesenian budaya daerah.

Kabupaten Gianyar memiliki kebudayaan yang beraneka ragam meliputi adat istiadat maupun kesenian. Salah satu kerajinan seni yang pernah mencapai masa emasnya di tahun 90 -an adalah kerajinan patung. Kerajinan seni patung yang sudah menembus pasar luar negeri sebagian besar digeluti oleh para pengrajin dan seniman daerah pedesaan Kabupaten Gianyar. Pengrajin patung tersebut berpusat di Desa Sebatu, Kecamatan Tegallalang.

Erupsi Gunung Agung yang terjadi pada akhir tahun 2017, sangat mempengaruhi citra Bali yang berimbas pada penurunan kunjungan wisatawan secara drastis. Kekhawatiran untuk berkunjung ke Bali dengan adanya Travel Warning yang dikeluarkan oleh pemerintah dari negara asal wisatawan, menyebabkan mereka mengurungkan niatnya untuk berwisata ke pulau dewata. Dampak yang ditimbulkan sangat dirasakan oleh seluruh stakeholder pariwisata. Bahkan, dua kali lipat dari tragedi bom Bali.

Hal inilah yang mengakibatkan kegiatan kepariwisataan sempat tersendat. Secara otomatis para pelaku pariwisata mengalami pengaruh yang cukup signifikan. Baik pelaku usaha akomodasi seperti hotel, resort, villa dan homestay yang kamarnya kosong selama berbulan-bulan. Hingga restoran, bahkan usaha industri kerajinan seni khususnya di daerah Gianyar. Oleh karena itu, penting untuk mengkaji tentang pengaruh erupsi Gunung 
Agung terhadap produksi kerajinan patung di Desa Sebatu, Kecamatan Tegallalang, Kabupaten Gianyar. Untuk menganalisis sejauh mana pengaruh erupsi Gunung Agung terhadap produksi kerajinan patung di Desa Sebatu, Kecamatan Tegallalang, Kabupaten Gianyar.

\section{TINJAUAN PUSTAKA}

Telaah penelitian sebelumnya sangat penting dilakukan untuk membandingkan antara penelitan sebelumnya dengan penelitian yang akan dilakukan berdasarkan fokus penelitian sehingga tidak terjadi penelitian ganda, serta untuk mengetahui apa keunggulan atau posisi dari penelitian yang ekarang dilakukan dibandingkan dengan penelitian yan sudah ada. Berdasarkan telaah penelitian sebelumnya yang pertama terkait dengan lokasi, yaitu "Strategi Pengembangan Wisata dan Dampak Kunjungan Wisatawan Studi Kasus: Pura Gunung Kawi di Desa Sebatu, Gianyar, Bali (I Made Sudjana, 2018)". Penelitian kedua yang terkait dengan fokus, yaitu "Patung Budha Sebagai Ikon Kerajinan Patung Kayu Di Kabupaten Gianyar (Ni Luh Gde Novitasari, dkk 2016)".

Adapun beberapa konsep yang digunakan sebagai pisau analisis dalam penelitian ini, sebagai berikut. Konsep produksi oleh Partadireja (1985). Konsep Industri Kerajinan oleh Wie (1994). Konsep seni patung oleh Myers (1958). Konsep erupsi gunung berapi oleh Sumintadireja (2000). Konsep saluran distribusi oleh Fuad (2006). Konsep jaringan oleh (Sjahrir 1995 dalam Pujani, 2000).

\section{METODE PENELITIAN}

Sumber data yang digunakan dalam penelitian ini, ada dua yaitu data primer dan data sekunder. Data primer merupakan sumber data yang langsung memberikan data kepada pengumpul data. Data tersebut meliputi data yang belum dipublikasikan dan diperoleh secara langsung dari sumber pertama melalui teknik pengumpulan data dari observasi dan wawancara tidak terstruktur (Sugiyono, 2014). Data primer yang dimaksud dalam penelitian ini adalah gambaran umum Desa Sebatu, pengaruh erupsi Gunung Agung terhadap produksi dan jaringan distribusi kerajinan patung di Desa Sebatu, Tegallalang. Data sekunder merupakan sumber data yang tidak langsung memberikan data kepada pengumpul data, misalnya melalui laporan penelitian terdahulu yang terkait dengan penelitian (Sugiyono, 2014). Data sekunder yang dimaksud dalam penelitian ini adalah profil Desa Sebatu, pengaruh erupsi Gunung Agung terhadap produksi dan jaringan distribusi kerajinan patung di Desa Sebatu, Tegallalang.

Teknik pengumpulan data dalam penelitian ini, antara lain : observasi, wawancara dan dokumen. Observasi dilakukan untuk mengamati secara langsung pengaruh erupsi Gunung Agung terhadap produksi maupun jaringan distribusi kerajinan patung di Desa Sebatu. Wawancara dilakukan untuk memperoleh data mengenai pengaruh erupsi Gunung Agung terhadap produksi maupun jaringan distribusi kerajinan patung di Desa Sebatu. Dokumen untuk mendapatkan data mengenai monografi Desa Sebatu.

Teknik analisis data yang digunakan dalam penelitian ini adalah teknik analisis data kualitatif menurut Seiddel (Bungin, 147 : 2007), sebagai berikut:

1. Mencatat yang menghasilkan catatan lapangan, dengan hal itu diberi kode agar sumber datanya tetap dapat ditelusuri.

2. Mengumpulkan, memilah-milah, mengklasifikasikan, menyintesiskan, membuat ikhtisar dan membuat indeksnya.

3. Berpikir, dengan jalan membuat agar kategori data itu mempunyai makna, mencari dan menemukan pola, dan hubungan-hubungan dan

4. Membuat temuan-temuan umum. Dalam penelitian ini, peneliti menggunakan teknik analisis data kualitatif yang dimulai dari mencatat dari hasil wawancara dan observasi sehingga menghasilkan catatan lapangan, kemudian memilah-milahnya, pada tahap selanjutnya peneliti hanya sampai pada tahap mencari hubungan-hubungan antar fenomena dari pengaruh erupsi Gunung Agung terhadap produksi kerajinan patung di Desa Sebatu. Hubungan yang dimaksud adalah hubungan sepihak antara pengaruh erupsi Gunung Agung terhadap produksi kerajinan patung di Desa Sebatu, hubungan antara pengaruh erupsi Gunung Agung terhadap intensitas produksi kerajinan patung, dan pengaruh erupsi Gunung 
Agung terhadap jaringan distribusi produk kerajinan patung di Desa Sebatu.

\section{HASIL DAN PEMBAHASAN}

\section{A. Desa Sebatu sebagai Sentra Kerajinan Patung}

Mengenai nama Sebatu, dikaitkan dengan cerita yang termuat dalam "Lontar Usana Bali" yaitu cerita Mayadanawa. Ketika terjadi peperangan antara Mayadanawa dengan Bhatara Indra, dimana Mayadanawa mengalami kekalahan. Kemudian ia melarikan diri kearah utara, upaya melarikan diri yang dilakukan oleh Mayadanawa untuk menghindari musuh itu hingga menyebabkan kakinya tesandung batu. Dalam bahasa Bali kata tersandung berarti "nyauh" berasal dari kata "sauh", yang perlahan mengalami peluluhan menjadi kata "Sebatu".

Berkembangnya pariwisata dengan sangat baik mulai mendongkrak pertumbuhan ekonomi, termasuk sentra industri kerajinan. Masyarakat Desa Sebatu mulai merintis usaha kerajinan patung pada tahun 80-an. Dimana masyarakat mulai membuat kerajinan patung di rumah masing-masing. Kemudian, banyak wisatawan yang berdatangan ke Desa Sebatu untuk melihat proses pembuatan kerajinan patung tersebut.

Pada saat kegiatan pariwisata semakin meningkat dan masyarakat mulai berinisiatif menyewa kios di pinggir-pinggir jalan untuk memajang hasil karya mereka dan hingga mencapai masa keemasannya pada tahun 90an, ditandai dengan adanya banyak pesanan yang datang untuk produksi massal kerajinan patung khususnya pengiriman ke pasar Internasional. Semenjak itu, Desa Sebatu menjadi sentra industri kerajinan patung yang eksistensinya masih bertahan hingga kini.

\section{B. Erupsi Gunung Agung}

Gunung Agung merupakan gunung tertinggi di Bali dan tergolong masih aktif. Sebelumnya, Gunung Agung telah mengalami letusan beberapa kali, yaitu pada tahun 1808, 1821, 1843, 1963. Terakhir letusan Gunung Agung yang paling besar terjadi tahun 1963 dan banyak menimbulkan korban jiwa. Pada akhir tahun 2017 tepatnya tanggal 14 September Gunung Agung kembali mengalami erupsi. Data kronologi aktivitas Gunung Agung yang telah dipantau oleh BMKG Provinsi Bali, pada periode bulan November, Gunung Agung telah mengalami tiga kali letusan Freatik. Letusan pertama terjadi tanggal 21 November 2017, kemudian letusan kedua terjadi tanggal 25 November 2017, ditandai dengan keluar asap tebal setinggi 1500 meter di atas puncak gunung. Erupsi Gunung Agung memasuki fase kritis pada tanggal 28 November 2017, ditandai dengan terjadi hujan batu pada radius $4 \mathrm{~km}$ dari kawah puncak.

Kronologi aktivitas erupsi Gunung Agung yang telah terekam dari pertengahan bulan September 2017 hingga bulan April 2018, mengakibatkan menurunnya kunjungan wisatawan datang ke Bali. Sehingga, keadaan ini juga berimbas langsung pada kegiatan pariwisata dan memberikan pengaruh terhadap sektor lain penunjang pariwisata, salah satunya pada sektor industri kerajinan.

\section{Intensitas Produksi Kerajinan Patung}

Kegiatan industri kerajinan mampu meningkatkan perekonomian masyarakat lokal dengan membentuk beberapa unit-unit usaha kerajinan kreatif. Sebagian besar dari masyarakat di Desa Sebatu mengandalkan kemampuan dan keterampilan yang mereka miliki untuk menggeluti berbagai jenis usaha kerajinan patung baik dalam skala kecil, menengah, hingga usaha besar.

1. Jenis Kerajinan Patung

Kerajinan patung yang diproduksi di Desa Sebatu tergolong dalam beberapa jenis, antara lain :

a. Patung kontemporer adalah patung yang berkembang sesuai zaman sekarang. Hasil produksi utama kerajinan patung kontemporer ini didominasi dengan patung binatang, diantaranya : patung kucing, jerapah, ayam, zebra, kodok, anjing, kelinci, burung hantu dan kuda.

b. Patung seni adalah jenis patung yang dibuat bertujuan sebagai karya seni murni dan memiliki estetika sebagai pajangan atau penunjang dekorasi untuk dinikmati keindahan bentuknya. Salah satu kerajinan yang tergolong patung seni adalah patung Garuda.

c. Patung religi adalah patung yang dibuat dengan tujuan sebagai saran beribadah dan bermakna religius bagi sebagian umat beragama. Patung yang paling mendominasi, diantaraya : berbagai jenis patung arca yang melalui proses upacara 
tertentu dapat distanakan sebagai simbol yang memiliki nilai sakral. Patung Arca merupakan patung perwujudan dari dewa-dewi yang penggambarannya sebagai manusia atau binatang dan digunakan sebagai sarana konsentrasi dalam persembahyangan. Jenis patung arca yang diproduksi, seperti : patung Budha, patung Dewi Kwan Im, patung Dewa Ganesha, patung Dewa Siwa, patung Dewa Krisna. Patung Arca ukurannya lebih besar, bahannya dari kayu pilihan seperti: cendana, dan cempaka.

2. Kapasitas Produksi Kerajinan Patung Kapasitas produksi kerajinan patung di Desa Sebatu dapat dibedakan menjadi dua, yaitu : melalui proses produksi dari bahan baku mentah hingga menjadi kerajinan patung siap jual dan hanya proses finishing kerajinan patung yang bahan setengah jadinya telah dibeli dari daerah Singapadu. Sehingga, terdapat perbedaan pada kapasitas produksi yang cukup signifikan antara keduanya. Karena, hasil proses kapasitas produksi hanya melalui proses finishing saja bisa mencapai dua kali lipat lebih banyak.

\section{Tabel Kapasitas Produksi Patung}

\begin{tabular}{|c|l|c|c|c|}
\hline No. & \multicolumn{1}{|c|}{ Jenis Patung } & K & M & B \\
\hline 1. & Kontemporer & & & \\
& - Kucing & 20 & 12 & $8 / \mathrm{hr}$ \\
& - Gajah & 10 & 5 & $1 / \mathrm{hr}$ \\
& - Zebra & 8 & 3 & $1 / \mathrm{hr}$ \\
& - Burung Hantu & 5 & 3 & $1 / \mathrm{hr}$ \\
& - Kodok & 6 & 2 & $1 / \mathrm{hr}$ \\
& - Jerapah & 12 & 6 & $3 / \mathrm{hr}$ \\
& - Ayam & 8 & 3 & $1 / \mathrm{hr}$ \\
& - Kelinci & 10 & 6 & $2 / \mathrm{hr}$ \\
& - Anjing & 8 & 5 & $1 / \mathrm{hr}$ \\
& - Kuda & 5 & 2 & $1 / \mathrm{hr}$ \\
\hline 2. & Seni & 2 & 1 & 1 \\
& - Garuda & & & $(2 \mathrm{hr})$ \\
\hline 3. & Religi & 6 & 3 & $1 / \mathrm{hr}$ \\
& - Budha & 6 & 3 & 1 \\
& - Dewi Kwan Im & & & $(2 \mathrm{hr})$ \\
& - Ganesha & 6 & 3 & 1 \\
& - Siwa & & & $(2 \mathrm{hr})$ \\
& - & & \\
& & &
\end{tabular}

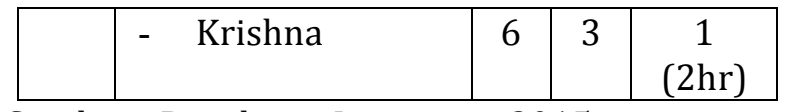

Sumber : Penelitian Lapangan, 2015

\section{Keterangan :}

$\mathrm{K}$ = Patung berukuran kecil.

$\mathrm{M}=$ Patung berukuran menengah.

$\mathrm{B}=$ Patung berukuran besar.

Kapasitas produksi yang telah dijabarkan merupakan hasil produksi dari bahan mentah hingga siap jual. Sedangkan, kerajinan patung yang telah dibeli setengah jadi dapat diproduksi hingga dua kali lipat dalam sehari. Para pengrajin patung di Desa Sebatu terbilang cukup cepat memproduksi kerajinan patung daripada kapasitas produksi kerajinan patung lainnya, meskipun memiliki bentuk dan ukuran yang sama. Karena, jenis patung produksi massal lebih mementingkan target penyelesaian produk sebanyak mungkin dalam jangka waktu tertentu. Sehingga, kerajinan patung yang produksi secara massal tidak terlalu menekankan pada setiap detail bentuk patung yang memiliki nilai seni tinggi. Hanya saja, pengrajin harus tetap mempertahankan keseragaman bentuk patung yang benar-benar sama dalam jumlah produksi sebanyak-banyaknya.

3. Sistem Kerja Pengrajin Patung

Sistem kerja yang diterapkan di Desa Sebatu hampir sama seperti jam operasional kerja pada umumnya selama delapan jam sehari, mulai dari jam 8 pagi hingga jam 5 sore. Terkadang pemilik usaha memberlakukan penambahan jam kerja yang terhitung lembur saat permintaan pesanan sudah mendekati waktu pengiriman. Biasanya lembur selama 3 jam dalam sehari dan terhitung mulai jam 7 sore hingga jam 10 malam. Pada saat terjadi erupsi Gunung Agung wisatawan yang datang langsung berkunjung ke artshop pemilik usaha sangat menurun secara drastis dan para pengrajin hanya mengerjakan permintaan kerajinan patung yang dipesan melalui email dalam jangka waktu beberapa bulan. Sehingga, pada periode akhir tahun 2017 pengrajin patung sangat jarang bekerja hingga lembur.

Sistem pemberian upah pada pengrajin patung di Desa Sebatu dapat dibagi menjadi dua jenis, yaitu : sistem borongan dan sistem upah harian. Pengrajin yang diberi upah harian bekerja di rumah pemilik usaha kerajinan dan 
hanya mengandalkan tenaga, karena semua bahan baku dan alat bantu kerja telah disediakan langsung. Sedangkan, untuk pengrajin borongan lebih dominan hanya diberi modal untuk membeli bahan baku dari awal untuk membuat kerajinan patung dan menggunakan alat bantu kerja milik pribadi. Besar kecilnya upah yang diterima oleh seorang pengrajin borongan sangat ditentukan oleh banyaknya kerajinan patung yang dapat diselesaikan sesuai kesepakatan antara pengrajin dengan pemilik usaha kerajinan. Rata-rata pengrajin borongan mendapatkan upah kurang lebih sekitar Rp.100.000.00 dalam sehari. Sedangkan untuk pengrajin harian, diberi upah sesuai keahliannya masing-masing. Untuk pengrajin yang baru belajar biasanya diberikan upah sebesar Rp.35.000.00 perharinya. Pengrajin yang sudah lama bekerja dan mampu mengerjakan lebih dari dua jenis pekerjaan sekaligus, dibayar hingga Rp.85.000.00 perharinya. Penambahan jam kerja untuk para pengrajin patung dihitung perjam sebanyak Rp.10.000.00, jadi mereka akan mendapatkan uang tambahan sekitar Rp.30.000.00 dalam sekali lembur.

Sistem pemesanan kerajinan patung di Desa Sebatu dapat dilakukan dengan tiga cara, yaitu : melalui telepon, via email, dan bertatap muka langsung. Karena, para pemilik usaha tidak memiliki rekapan tertulis yang memperlihatkan hasil penjualan kerajinan patung dalam rentang waktu tertentu. Selain itu, pendapatan pemilik usaha kerajinan tergantung pada banyaknya wisatawan yang datang untuk membeli secara langsung ke artshop dan pesanan yang diterima langsung melalui email maupun melalui telepon. Pada saat wisatawan masih ramai berkunjung, para pemilik usaha kerajinan mampu menjual kerajinan patung mencapai sekitar Rp.400.000.000.00 selama sebulan. Namun, saat terjadinya erupsi Gunung Agung dapat diperkirakan omset penjualan kerajinan patung di Desa Sebatu menurun sekitar 40\% kurang lebih sekitar Rp.160.000.000.00 kerajinan patung yang terjual dalam sebulan.

Sistem kerja para pemilik usaha kerajinan patung di Desa Sebatu terkait dengan keterbatasan modal, rata-rata mengelola modal yang dimiliki dengan cara menekan beberapa pengeluaran biaya operasional tertentu untuk mengembangkan usaha kerajinan yang dimiliki, baik itu untuk membiayai upah tenaga kerja yang cenderung meningkat maupun membeli alat bantu kerja berupa mesin-mesin, atau teknologi lain yang digunakan untuk mendukung proses produksi kerajinan patung secara maksimal. Biasanya pada saat modal usaha yang mereka miliki mulai menipis, pemilik usaha kerajinan patung akan berusaha meminjam modal dari Bank atau lebih memilih mendapatkan modal usaha ke penggadaian. Sedangkan, bagi para pengrajin kecil yang tidak memiliki modal biasanya dibantu oleh pemilik usaha kerajinan patung menengah keatas dengan bantuan dana atau bahan untuk memproduksi kerajinan patung dari tempat usaha tersebut. Sistemnya seperti pengrajin borongan, hanya saja pengrajin kecil ini biasanya difasilitasi dengan alat bantu kerja berupa pahatan atau cat dan mereka bisa bekerja secara bebas di rumah masing-masing. Terkadang ada juga beberapa pengrajin kecil yang menitipkan hasil kerajinan patung yang mereka buat agar dipajangan pada artshop pemilik usaha. Namun, jika pengrajin kecil ini memiliki kebutuhan modal usaha secara mendesak, beberapa dari mereka akan meminjam modal di koperasi seniman yang bunganya jauh lebih sedikit daripada di Bank.

\section{Hubungan Pengaruh Erupsi Gunung Agung terhadap Intensitas Produksi Kerajinan Patung}

Intensitas produksi kerajinan patung di

Desa Sebatu sempat melemah sekitar 30\% akibat terjadinya erupsi Gunung Agung. Hal ini ditandai dengan menurunnya tingkat kunjungan wisatawan yang datang langsung ke artshop pemilik usaha kerajinan patung di Desa Sebatu yang dipengaruhi oleh erupsi Gunung Agung. Padahal para pemilik usaha kerajinan patung mengakui pembeli yang datang langsung ke tempat usaha mereka terbilang cukup menjanjikan, selain pembeli dari langganan luar negeri yang memesan kerajinan patung melalui email. Karena, kebanyakan pembeli langganan dari luar negeri yang juga menekuni dunia bisnis sebagai pedagang lebih mengerti harga bersaing dipasaran dan selalu menawar harga sesuai jumlah pesanan kerajinan patung yang ditargetkan untuk dibeli. Kemudian hasil produksi kerajinan patung tersebut akan kembali mereka jual di negara asalnya. 
Sebelum terjadinya erupsi Gunung Agung, pengrajin patung di Desa Sebatu hampir setiap hari menerima pesanan dari wisatawan yang datang berkunjung secara langsung ke artshop pemilik usaha dan mampu memproduksi lebih banyak kerajinan patung ditambah waktu lembur yang diberlakukan untuk mengejar target pengiriman. Sehingga, permintaan akan kerajinan patung mulai menurun dan secara otomatis mempengaruhi kapasitas produksi. Namun, intensitas produksi kerajinan patung di Desa Sebatu pasca erupsi Gunung Agung sudah mulai menguat dan kembali berjalan normal.

\section{E. Jaringan Distribusi Produk Kerajinan Patung}

Para pemilik usaha kerajinan patung di Desa Sebatu memiliki lima jenis jaringan distribusi, yaitu : penyaluran pada pasar seni Sukawati, penyaluran pada Cening Bagus oleholeh khas Bali, pengiriman dengan kontainer melalui jalur laut, pengiriman melalui kargo dan pengiriman ke villa.

1. Penyaluran ke Pasar Seni Sukawati

Beberapa pemilik usaha kerajinan patung di Desa Sebatu menyalurkan hasil produksi mereka ke Pasar Seni Sukawati dan ada juga beberapa dari mereka yang langsung menyewa kios di Pasar Seni Sukawati. Semua jenis dan ukuran kerajinan patung disalurkan langsung ke Pasar seni Sukawati agar produk yang ditawarkan lebih beragam dan memberikan banyak pilihan pada pembeli. Setelah hasil produksi kerajinan patung dikirim untuk dijual, biasanya akan ada banyak pedagang lain yang membeli kerajinan patung tersebut dari Pasar Seni Sukawati untuk dijual kembali di toko mereka. Sehingga, di Pasar Seni Sukawati telah terjadi sistem distribusi secara berantai.

Penyaluran ke pasar seni Sukawati biasanya dilakukan sekitar seminggu sekali. Para pemilik usaha kerajinan patung mengandalkan pengiriman hasil produksi patung mereka untuk yang berukuran kecil hingga sedang biasanya diangkut menggunakan mini bus. Sedangkan, untuk patung yang berukuran besar sekitar satu hingga dua meter dikirim menggunakan mobil carry terbuka. Kerajinan patung yang banyak disukai oleh pembeli adalah jenis patung kontemporer kucing dan gajah yang memiliki bentuk unik. Namun, semenjak erupsi Gunung Agung yang menyebabkan menurunnya tingkat kunjungan wisatawan berpengaruh langsung pada penyaluran kerajinan patung ke Pasar Seni Sukawati yang kemudian dilakukan sekitar sebulan sekali. Namun, untuk saat ini penyaluran hasil produksi kerajinan patung ke Pasar Seni Sukawati sudah kembali normal.

2. Penyaluran ke Oleh-oleh Khas Bali

Penyaluran kerajinan patung ke OlehOleh Khas Bali dilakukan para agen dari Cening Bagus yang telah bekerjasama dengan pemilik usaha kerajinan patung di Desa Sebatu. Agenagen tersebut akan datang langsung ke rumah produksi pemilik usaha kerajinan patung di Desa Sebatu untuk membeli kerajinan dalam berbagai bentuk dan ukuran. Selain kerajinan patung, agen dari Cening Bagus Oleh-Oleh Khas Bali juga membeli kerajinan topeng, souvenir binatang kecil dengan corak warna-warni dan mirror frame. Sedangkan, khusus untuk kerajinan patung yang dibeli lebih didominasi dengan patung Budha, relief Budha, relief Flora Fauna dan jenis patung Dewa Krisna. Kedatangan para agen dari Cening Bagus oleholeh khas Bali sekitar dua minggu sekali.

Namun, semenjak menurunnya tingkat kunjungan wisatawan datang ke Bali akibat dari pengaruh erupsi Gunung Agung juga mempengaruhi kegiatan transaksi jual beli kerajinan patung di Cening Bagus Oleh-Oleh Khas Bali. Sehingga, pembelian kerajinan patung dari agen tersebut juga mulai berkurang sekitar sekali dalam satu bulan. Namun, untuk saat ini penyaluran hasil produksi kerajinan patung ke Cening Bagus Oleh-Oleh Khas Bali sudah kembali normal.

3. Pengiriman melalui Jalur Laut

Hasil produksi kerajinan patung yang dikirim melalui jalur laut akan disalurkan dengan menggunakan kontainer. Pengiriman melalui kontainer biasanya dilakukan setiap tiga bulan sekali untuk dua kali pengiriman yang waktunya tidak menentu. Karena, seberapa banyak kerajinan patung yang cukup dimuat untuk sekali angkut dalam satu kontainer dikirim secara bertahap sampai semua pesanan terkirim. Biasanya dalam satu kontainer wisatawan tidak hanya membeli kerajinan patung di satu tempat usaha kerajinan. Sehingga, kerajinan patung yang akan dikirim sangat bervariasi baik itu jenis maupun ukurannya. Mulai dari patung budha, 
relief, dan patung binatang, seperti : jerapah, kucing, zebra, burung hantu, gajah dan kuda.

Akibat erupsi Gunung Agung akses transportasi melalui jalur laut sempat terhambat. Karena, semburan abu vulkanik yang menghalangi jarak pandang dan dikhawatirkan dapat memicu terjadinya kecelakaan. Sehingga pada awal bulan Februari 2018, pengiriman kerajinan patung sempat tertunda sekitar dua minggu di pelabuhan Gilimanuk. Meskipun sempat tertunda, saat ini proses pengiriman kerajinan patung melalui jalur laut telah kembali berjalan normal.

\section{Pengiriman melalui Kargo}

Khusus untuk pengiriman melalui kargo, wisatawan yang datang langsung memesan kerajinan patung di Desa Sebatu akan menentukan kargo mana yang dipilih untuk mengirim pesanan mereka. Kemudian, kargo yang telah ditunjuk pembeli untuk mengantarkan pesanan tersebut akan langsung datang untuk mengambil hasil produksi kerajinan patung, lalu dikirim sesuai kesepakatan antara pemilik usaha kerajinan dan pembeli. Kerajinan patung yang dikirim melalui kargo sama halnya dengan produk yang dikirim melalui kontainer, dimana kerajinan patung sangat bervariasi jenis dan ukurannya sesuai permintaan pembeli.

Pengiriman hasil pesanan kerajinan patung biasanya dilakukan sekitar dua kali dalam sebulan. Namun, saat erupsi Gunung Agung terjadi permintaan pembeli cukup jarang dan pengiriman kargo menurun menjadi dua sampai tiga bulan sekali, terhitung dari periode awal bulan Oktober hingga akhir Desember 2017. Sedangkan, untuk saat ini pengiriman hasil produksi kerajinan patung melalui kargo sudah kembali normal sesuai permintaan pembeli.

\section{Pengiriman ke Villa}

Pemilik usaha kerajinan patung di Desa Sebatu menjalin kerjasama dengan beberapa pemilik villa di daerah Payangan. Pemilik villavilla ini ingin lebih menekankan nuansa ethnic tradisional yang disukai wisatawan. Suasana inilah yang membuat mereka merasa nyaman saat menghabiskan waktu bermalam di villa tersebut dengan suasana yang cukup unik dan berbeda dari villa-villa pada umumnya. Para pemilik usaha kerajinan patung di Desa Sebatu biasanya mengirimkan hasil produksi kerajinan patung mereka ke Villa Vano dan Villa Song
Beruk. Adapun jenis patung yang dikirim berupa relief budha dan flora fauna serta berbagai patung binatang kecil untuk menghias kamar di villa tersebut. Selain itu, berbagai jenis furniture unik sebagai interior juga dipesan oleh pemilik villa dengan desain yang telah mereka tentukan sendiri.

Pengiriman kerajinan patung ke villa biasanya dilakukan setiap ada desain baru yang ditawarkan oleh pemilik usaha kerajinan patung di Desa Sebatu. Setiap satu kali pengiriman pemilik usaha kerajinan patung dapat mengisi full mobil box dengan berbagai jenis patung dan ukuran yang bervariasi. Khusus untuk pengiriman hasil produksi kerajinan patung ke villa-villa tersebut tidak mengalami kendala akibat erupsi Gunung Agung.

\section{F. Hubungan Pengaruh Erupsi Gunung Agung terhadap Jaringan Distribusi Kerajinan Patung}

Jaringan distribusi kerajinan patung di Desa Sebatu, khususnya pengiriman melalui kargo pesawat yang sangat terhambat akibat diberlakukannya sistem penutupan bandara I Gusti Ngurah Rai selama erupsi terjadi dan menyebabkan penumpukkan hasil produksi kerajinan patung di kargo. Penyaluran distribusi kerajinan patung ke Pasar Seni Sukawati, Oleh-Oleh Khas Bali dan pengiriman melalui jalur laut juga sempat mengalami hambatan yang mempengaruhi waktu pengiriman semakin menurun hingga dua kali lipat dari biasanya. Sedangkan, erupsi Gunung Agung tidak berpengaruh pada pengiriman hasil produksi kerajinan patung ke villa-villa tersebut.

Saat erupsi Gunung Agung terjadi para pengrajin patung di Desa Sebatu hanya mampu memproduksi beberapa jenis kerajinan sebagai persediaan semata, sambil menunggu proses pengiriman hasil produksi kerajinan sebelumnya yang sempat terhambat dapat kembali normal. Karena, menurunnya kunjungan wisatawan ke Bali berpengaruh pada kegiatan transaksi pembelian kerajinan patung dan jangka waktu pengiriman yang semakin jarang. Sehingga, erupsi Gunung Agung berpengaruh secara signifikan terhadap jaringan distribusi kerajinan patung di Desa Sebatu. Namun, saat ini jaringan distribusi 
kerajinan patung pasca erupsi Gunung Agung telah berjalan stabil dan mulai normal kembali.

\section{PENUTUP}

\section{A. Kesimpulan}

Berdasarkan hasil penelitian yang berjudul Pengaruh Erupsi Gunung Agung terhadap Produksi Kerajinan Patung di Desa Sebatu, Kecamatan Tegallalang, Kabupaten Gianyar, maka dapat ditarik kesimpulan sebagai berikut:

1. Intensitas produksi kerajinan patung meliputi aspek-aspek sebagai berikut : jenis kerajinan patung yang diproduksi di Desa Sebatu, antara lain : patung kontemporer (binatang), patung relief dan patung religi. Kapasitas produksi kerajinan patung di Desa Sebatu dapat dibedakan menjadi dua, yaitu : proses produksi dari bahan baku mentah hingga menjadi kerajinan patung siap jual dan proses finishing kerajinan patung yang bahan setengah jadinya telah dibeli dari daerah Singapadu. Sistem kerja yang diterapkan di Desa Sebatu dibagi menjadi dua, yaitu : pengrajin yang diberi upah harian dan pengrajin borongan yang diberi upah sesuai dengan jumlah kerajinan patung yang diselesaikan. Hambatan produksi yang dialami oleh para pemilik usaha kerajinan patung di Desa Sebatu dipengaruhi faktor internal, seperti : modal, bahan baku, alat bantu kerja, dan tenaga kerja. Hubungan pengaruh erupsi Gunung Agung berimbas pada permintaan kerajinan patung yang mengandalkan kedatangan wisatawan untuk memesan secara langsung menjadi berkurang dan mengurangi kapasitas produksi kerajinan patung sehingga kapasitas produksi pada saat terjadinya erupsi sempat melemah. Sehingga, erupsi Gunung Agung berpengaruh cukup signifikan terhadap intensitas produksi kerajinan patung di Desa Sebatu.

2. Jaringan distribusi produk kerajinan patung di Desa Sebatu dapat disalurkan dengan lima cara, yaitu : penyaluran ke Pasar Seni Sukawati, penyaluran ke Oleh-Oleh Khas Bali, pengiriman melalui jalur laut dengan kontainer, pengiriman melalui kargo pesawat dan pengiriman ke villa. Pengaruh erupsi Gunung Agung menyebabkan terhambatnya proses pendistribusian kerajinan patung melalui kargo pesawat, hal ini diakibatkan oleh berlakunya sistem buka tutup bandara. Penyaluran distribusi kerajinan patung ke Pasar Seni Sukawati, Oleh-Oleh Khas Bali dan pengiriman melalui jalur laut juga sempat mengalami hambatan yang mempengaruhi waktu pengiriman semakin menurun hingga dua kali lipat dari biasanya. Sedangkan, erupsi Gunung Agung tidak berpengaruh pada pengiriman hasil produksi kerajinan patung ke villa-villa tersebut. Oleh karena itu, erupsi Gunung Agung berpengaruh cukup signifikan terhadap produksi dan jaringan distribusi kerajinan patung di Desa Sebatu.

\section{B. Saran}

Adapun saran yang dapat diberikan, sebagai berikut:

1. Sebaiknya Pemerintah Kabupaten Gianyar memberikan bantuan modal industri kerajinan patung khususnya di Desa Sebatu, agar mampu memberi motivasi kepada para pengrajin untuk memulai usaha secara mandiri dan meningkatkan hasil produksi mereka.

2. Peranan pemerintah sangat penting dalam upaya memfasilitasi para pengrajin untuk membantu mereka mempromosikan hasil produksi kerajinan. Baik melalui website resmi atau mengikuti beberapa event atau pameran di tingkat nasional maupun Internasional.

3. Strategi marketing masih harus lebih ditingkatkan baik dengan promosi melalui media massa maupun internet, agar mampu memudahkan wisatawan untuk mengakses hasil produksi kerajinan patung di Desa Sebatu, sebagai pusat kerajinan patung di Kabupaten Gianyar.

\section{DAFTAR PUSTAKA}

Bungin, B. 2007. Penelitian Kualitatif : Komunikasi, Ekonomi, Kebijakan Publik, dan Ilmu Sosial Lainnya. Jakarta : Kencana. 
Creswell, J W. 2012. Research Design Pendekatan Kualitatif, Kuantitatif, dan Mixed. Yogyakarta : Pustaka Pelajar.

Fuad. 2006. Pengantar Bisnis. Jakarta: Gramedia Pustaka Utama, H. 129.

Moleong, L. 2005. Metode Penelitian Kualitatif. Bandung: PT. Remaja Rosdakarya.

Myers, B.S. 1958. Understanding the Arts. New York: Holt Rinehart and Winston

Novitasari, L G dkk. 2016. "Patung Budha sebagai Ikon Kerajinan Patung Kayu di Kabupaten Gianyar". Jurnal Bakti Saraswati Vol. 05 No. 02. ISSN : 20882149 : Denpasar.

Okayana, I G A P A dan Suryasih, I. 2015. "Identifikasi Potensi Pasiraman Pura Dalem Pingit Lan Pura Kusti Di Desa Sebatu, Gianyar Sebagai Wisata Spiritual". Jurnal Destinasi Pariwisata Vol. 3 : Denpasar.

Partadireja, A. 1985. Pengantar Ekonomi. Yogyakarta. BPFE-UGM.

Pujani, L P K. 2000. "Pekerja Anak pada Sektor Informal Penjual Post Card di Objek Wisata Tanah Lot, Tabanan, Bali (Studi Tentang Pemaknaan Kerja dalam Perspektif Budaya Kewiraswastaan)". Tesis. Denpasar : Program Pascasarjana, Universitas Udayana.

Sugiyono. 2014. Metode Penelitian Kuantitatif dan R\&D. Bandung : Alfabeta.

Sumintadireja, P. 2000. Catatan Kuliah Volkanologi. Bandung : ITB.

Telagawathi, N L, dkk. 2016. "Pemberdayaan Industri Kecil Kerajinan Tangan Melalui Pengembangan Kewirausahaan Di Kabupaten Gianyar Bali". Jurnal Senari ISBN 978-602-6428-04-2 : Denpasar.

Wie, T K. 1994. Industrialisasi di Indonesia. Jakarta : Pustaka LP3ES.

Yoeti, A. 2008. Perencanaan dan Pengembangan Pariwisata, cetakan kedua. Denpasar : PT.Pradnya Paramita. 